\title{
REFORMING THE PRESIDENTIAL NOMINATING PROCESS
}

\author{
PaUl T. David*
}

It is the function of the presidential nominating process to identify the candidates who can be made the subject of a presidential election; it is the function of the general election to make the final choice. Because of this characteristic difference in function, the nominating process differs from the general election process in respects that are fundamental to the manner in which each should be conducted.

An election for President, as long as the two-party system holds together, is essentially a choice between two candidates, each of whom was formally identified some time in advance, has become familiar to the voters through active campaigning, and has the support in the election of a permanently organized national political party. None of these features is true of the nominating process. It has to begin in the first place by ascertaining the alternatives among whom a choice may be made, seldom deals with a choice between two candidates and only two, frequently involves a comparison between some candidates who are well known and others who are little known and goes on inside the political party from which support will be obtained-after the choice has been made.

Much of what is most important in the nominating process occurs before there is any short list of definite candidates on whom to concentrate attention. These aspects of the process will be neglected here, moving on immediately to special characteristics of the nominating choice that become apparent after the field of candidates for a party nomination has become relatively clear. ${ }^{1}$

\section{Some Characteristics of Presidential Nominating Choice}

I. In many cases-about one-third of the total in the two-party experience since r832-there is little or no serious consideration of alternative candidates for the party nomination because an overwhelming preference for a single candidate is obvious.

Most of these cases have involved the re-nomination of a successful first-term

- B.A. 1928, Antioch College; M.A. 1930, Ph.D. I933, Brown University. Professor of Political Science, University of Virginia. Co-author, Vol. I, and co-editor, Vols. II-V [with Malcolm Moos \&* Ralph M. Goldman], Presidential Nominating Politics in 1952 (1954); [with Ralph M. Goldman \& Richard C. Bain] The Politics of National Party Conventions (1960); [with others] The Presidenttal Election and Transition ig60-6I (196I).

For assistance in maturing the analysis herein the author is especially indebted to Duncan Black, University College of North Wales; Ralph M Goldman, University of Chicago; Louise Overacker, Wellesley College; William H. Riker, Lawrence College; and Gordon Tullock, University of Virginia; also to three of the students in his advanced seminar, Alexander B. Lacy, Jr., Robert L. Lester, Jr., and David G. Temple.

${ }^{1}$ On the prior problems of preparation and candidate advancement, see PAUz T. DAvid, RALPH M. Goldman \& Richard C. Bain, The Politics of National Party Conventions, ig6o, at chs. 4-7, i3, and at $483-88$. 
President. Others have involved non-incumbents who had achieved so strong a position that no important challenger came forward, as in the nomination of Herbert Hoover in 1928 and Alfred M. Landon in 1936.

2. The candidate who would probably be most highly preferred for a party nomination is not always definitely available, especially if availability involves a positive course of action and personal responsibility for self-advancement.

This is a recurring problem for parties that find themselves in a position of weakness, and sometimes for those that do not. General Dwight D. Eisenhower was unwilling to accept availability in 1952 until after he had seen the outcome of the New Hampshire and Minnesota primaries. Governor Thomas E. Dewey had excellent reasons for not wishing to become available in 1944. Charles Evans Hughes, the near-winner of 1916 , was unwilling to become available in 1920 , even when the prospect of a deadlocked convention was already evident.

3. When the situation is such that alternative candidates are seriously considered, the number of principal candidates is seldom as small as two.

Candidates for a party nomination may be found among the fifty governors, the hundred senators, holders of other official positions, and persons in private life. The national situation differs sharply in this respect from that in an individual state when candidates for governor or senator are being sought. The structure of the channels of advancement in the direction of the Presidency is such that a multiplicity of candidates can readily become available in any open nominating situation, thus complicating the problem of choice.

4. In situations involving three or more principal candidates for a party nomination, commonly no candidate is preferred by a majority on a first-choice basis.

This is what one might suppose from the mere fact of numbers. It is confirmed empirically by the public opinion data for the period since 1936 , and can be inferred from the structure of voting at the party conventions for the entire period of convention experience. In all such situations, arrival at a majority choice involves repeated voting with a revision of preferences, or some process of eliminating one or more of the candidates, or some system of counting that takes account of preferences ranking lower than those on a first-choice basis.

5. Nominating situations that do bi-polarize around two principal candidates of nearly equal strength can become situations of special danger for the political party concerned.

This kind of a contest, which has virtue in a general election because it tends to maintain the vitality of the two-party system, is especially undesirable within a single political party because of its tendency to produce, maintain, and enhance a dual factionalism within the party. It can be deeply divisive, as in the contest between Alfred E. Smith and William G. McAdoo in 1924, or that between Robert A. Taft and Dwight $D$. Eisenhower in 1952. In the Smith-McAdoo contest, neither could be nominated at the Democratic Convention under the two-thirds rule then in effect, and the result was a nominee who proved hopelessly inadequate as a vote-getter. 
In the Taft-Eisenhower contest, the Eisenhower nomination led on to electoral victory, partly because of his strength outside of the party, but also because he was in a position to conciliate the Taft faction. If Taft had been nominated, quite different results might have occurred.

6. In situations in which several candidates are under consideration, preferences in regard to the candidates are frequently weak and highly unstable.

Among Republican voters in 1948, for example, those preferring Harold E. Stassen as their first choice rose from fifteen per cent in February to thirty-seven per cent in May, declining after the Oregon primary to twenty-six per cent in June. During this same period, Thomas E. Dewey's rating declined from thirty-eight per cent in February to twenty-four per cent in May, when he was trailing Stassen, and recovered to thirty-three in June. The standing of the other principal potential candidates fluctuated during the same period, with Robert A. Taft losing strength from a high of fifteen per cent, Arthur Vandenberg gaining strength to a high of thirteen per cent, and Douglas MacArthur first gaining to nineteen per cent, then losing to eleven.2

A similar oscillation occurred among the Democratic candidates in 1956, with Adlai Stevenson's Democratic voter preference rising to fifty-one per cent in March, declining to thirty-nine in April and rising to forty-five in late June, while Estes Kefauver's position on the same scale was rising from eighteen per cent in March to thirty-three in April and then declining to sixteen in late June, with Averell Harriman remaining well behind both of the leading possibilities but gaining strength as the convention approached. ${ }^{3}$

\section{Vote-Counting Theory in Nominating Choice}

An obvious conclusion would seem to follow from the characteristics just outlined. The problem of nominating choice does not easily lend itself to a satisfactory solution-at the presidential level and in a country as complicated as this one-through any ordinary form of election that could be applied uniformly on some standardized basis. The extent to which this is true can probably be most clearly demonstrated by assuming, for the moment, that it would be possible to create a national primary election in which all of the appropriate candidates would be entered and that would attract a full turnout of the voters of each party. The consequences of such an election system for the supply of candidates, the character of nominating campaigns, the structure of the party system, and the conduct of the government can also be neglected for the present, in order to deal directly with an essentially theoretical point: Would it be possible to create a system of voting and vote-counting in such an election that would assuredly result in the selection of the most appropriate candidates?

The problem involved in this question arises most frequently from situations in one party or the other in which there is no majority preference on a first-choice basis.

${ }^{3}$ David, Goldman \& Bain, op. cit. supra note 1 , at 313 , using Gallup Poll data.

IId. at 3 I3. 
In state primary elections to nominate candidates for governor or senator, the problem has been typically solved in one of two ways: either the highest ranking candidate in the primary is given the nomination, even though his plurality may fall short of a majority, or a run-off election is held between the two highest candidates.

Almost no one has had the temerity to suggest the first solution at the presidential level. The second is currently embodied in various proposals pending in Congress, but it would seem nonetheless to be a very unsatisfactory solution. It is probably an unsatisfactory solution at the state level; but there, at least, its consequences are only indirectly involved in the problems of representativeness and stability in the national political system.

The basic difficulty with the run-off solution is the fact that it can easily fail to produce the candidate who would be most preferred. The possibility of such failure is capable of mathematical demonstration if a system of counting is used that takes account of the entire structure of preference and not merely the first-choice preferences.

To take a simple example of a kind that is familiar to all politicians, suppose that there are three candidates, A, B, and C, who are preferred respectively on a first-choice basis by forty, twenty-five, and thirty-five per cent of the party voters. $\mathrm{A}$ and $\mathrm{C}$, however, occupy opposite positions on the party spectrum, with the result that each is at best only a third choice for the other's supporters, who would much prefer to have the center man, $B$, if they cannot have their first choice. The supporters of $B$, on the other hand, are divided in their second choice preferences, fifteen per cent preferring $A$ and ten per cent preferring B. A little arithmetic will demonstrate that if each pair of possible candidates were to be voted on separately, $B$ would defeat $A$ by 60 to 40 and $C$ by 65 to 35 ; $A$ would lose to $B$ while defeating $C$ by 55 to 45 ; and $C$ would lose to both $B$ and $A$. Yet in a run-off after an ordinary type of primary, $B$ would be eliminated and the run-off would be held between $A$ and $C$, who would rank first and' second on a first-choice basis. The same failure to nominate $B$ would also occur if no run-off were held, and the plurality on the first election was accepted as final.

This kind of analysis has been applied to a wide range of electoral situations and voting systems by a British economist, Professor Duncan Black. ${ }^{4}$ His book also reviews the principal contributions of earlier mathematical investigations of elections theory; and it was recently referred to by Professor William H. Riker as "one of the most important books on political theory to be published in this century." It was my loss, and that of my colleagues, that this book did not come to our attention until after The Politics of National Party Conventions was already on its way to press; we took some account of Black's work, but not as much as it merited. ${ }^{6}$

- Duncan Black, The Theory of Commirtees and Elections (1958).

${ }^{8}$ Riker, Voting and the Summation of Preferences: An Interpretive Bibliographical Reviest of Selected Developments During the Last Decade, 55 AM. PoL. Scr. REv. 900-I I (I96r).

"David, Golmann \& BaIN, op. cit. supra note r, at 315 n.24, 489 n.7. On further consideration, it 
Black searched assiduously for some general rule that could be used to determine what candidate is best when no candidate has a first-choice majority; and he concluded that probably the best rule was one proposed by Condorcet some two centuries ago: that candidate should be preferred, if there is one, who can defeat each of the others when paired against him on a direct vote; and further, according to Black, if it is demonstrated that there is no such candidate, that candidate should be chosen for whom there seems to be the highest average preference, as judged by a method of marks. ${ }^{7}$

The possibility that there may be no single majority candidate who can defeat each of the others on direct, paired votes involves the type of situation in which candidate $A$ is preferred to $B$ and candidate $B$ is preferred to $C$-which would seem to imply that candidate $A$ would be preferred to $C$-but it is found in fact that candidate $C$ is preferred to $A$. This is the situation in which social choice is not transitive; a situation that has been much discussed by American economists as the result of the work of Kenneth J. Arrow, most notably his monograph in I95I on

would seem that Black has destroyed the case for the Australian type of alternative vote, which we discussed at pp. $237-39$ and 315 ; see BLACK, op. cit. supro note 4 , at 69-74. Black proves, using a fivecandidate example, that the Australian system can easily eliminate the candidate who would be the majority preference if tested against each of the other candidates, one at a time.

Under the Australian system, if five candidates are in the running for a single position, each voter ranks his preference on the ballot for all five. If one of the five has a first-choice majority, he is elected; if not, the candidate ranking lowest on a first-choice basis is eliminated and his ballots are distributed on the basis of their second-choice preferences, and so on, until a majority choice is found.

Black's analysis suggests that the system should be inverted: In the situation described, if no candidate has a first-choice majority, the first candidate to be eliminated should be the one with the largest number of last-choice votes rather than the one with the smallest number of first-choice votes. Applied to Black's five-candidate example, this system would result in the selection of the candidate who could defeat each of the others on a single-pairing basis. It would also have this result if applied to the threecandidate example previously used in the text. Candidate A would have been the third-choice (lastchoice) of $45 \%, \mathrm{~B}$ of none, and C of $55 \%$. Candidate $\mathrm{C}$ would thus be the first candidate to be eliminated, B would then receive the second-choice votes of C's supporters and would be elected by $60 \%$ of the vote.

Unfortunately, it is not difficult to construct hypothetical examples in which the system of eliminating the non-majority candidate with the largest number of last-choice votes can lead to a paradoxical outcome. Illustrations provided by Professors Black and Tullock suggest that this is most likely to occur when the candidate ranking highest in first-choice strength is also the one attracting the most intense opposition. No doubt such cases can happen in actuality; whether they happen very often is a problem for empirical investigation. Even a minimum of classroom experimentation with a ballot offering Rockefeller, Nixon, Romney, and Goldwater as candidates for the Republican nomination of 1964 will readily demonstrate that the distribution of last-choice votes is no simple inversion of the distribution of first-choice votes. This is a type of experimentation that can be recommended to any instructor who is trying to enlighten his students on the problems of choice that are faced by a national party convention.

${ }^{7}$ BLıcK, op. cit. supra note 4, chs. 9 and Io, esp. 57,66,74-75. Under the method of marks, if there are four candidates, for example, each voter gives three marks to his first-choice candidate, two to the next, one to the next, and zero to his last choice. The candidate with the highest total count is considered the one with the highest average preference and is elected. In' an actual primary with several candidates in which each voter recorded his entire preference list, the amount of vote counting involved in determining which candidate could defeat each of the others would probably become excessive, unless a ballot is devised that can immediately be fed into a mechanical computer. What Black calls the method of marks, however, would probably be practical and might be preferable as a general system in order to deal with any cases of nontransitivity that may occur; a run-off could also be provided between the two highest candidates as computed by the method of marks in any case where no candidate had a first-choice majority. 
Social Choice and Individual Values. The same problem had been discovered by Condorcet and is known in France, according to Riker, as l'effet Condorcet; and it was also discovered by C. L. Dodgson (Lewis Carroll), who called it the problem of cyclical majorities. ${ }^{8}$

The "Arrow problem"-a nontransitivity of social choice-is a problem that can undoubtedly arise frequently in voting on substantive policy; basically it is the result of cross-cutting value systems in a situation of multiple alternatives. ${ }^{0}$ Something of this kind probably underlies the current difficulties in the way of congressional action on federal aid to public and private schools. For the purposes of this article, however, the question that needs an answer, but which at present has none, is whether or not nontransitivity is a frequently recurring problem in the field of nominating choice.

In the most recent relevant instance, the Kennedy nomination of 1960 , it was my conclusion in a previous study, on the basis of the Gallup Poll evidence, that Kennedy probably could have defeated each of his opponents at the time of the convention if paired against each of them singly in a national primary open to Democratic voters. Early in the year, Kennedy was preferred to Stevenson, fifty per cent to forty-three; Kennedy was preferred to Johnson, fifty-eight per cent to thirty-two; Johnson was preferred to Symington, forty-seven per cent to twenty-eight; and presumably Kennedy was preferred to Symington by some large ratio, although figures are not available, and the proof is thus not complete. By the time of the convention, Kennedy's position in all of these pairings had probably strengthened, since his firstchoice position had gone up from thirty-five per cent to forty-one per cent. ${ }^{10}$ There was no evidence of nontransitivity in the situation, although the injection of the religious issue undoubtedly produced a situation of cross-cutting values.

The continuing services of the Gallup Poll may help to eliminate cases of nontransitivity whenever they do have a tendency to appear in connection with presidential nominations. This could occur in each of two ways: (I) The trial heat data of the Gallup Polls, in which candidates of one party are tested against candidates of the other, tend to produce a rank order of the candidates within each party in terms of their ability to defeat the strongest candidate available to the other party. ${ }^{11}$ This, it would seem, would have to be a transitive ranking; and it undoubtedly exercises an influence on the structure of preferences within each party that would tend to

\footnotetext{
'Black's proof that Dodgson's work on elections theory owed little to his predecessors includes the dry comment that the proceedings of the French Academy for $178 \mathrm{I}$ were still resting in Christ Church Library with the appropriate pages uncut when Black himself came to examine them; and while Christ Church had no copy of Condorcet's Essai, there was a copy in the Bodleian in which one of the pages of the section on elections was still uncut. Dodgson's work on elections theory seems to have arisen from an intense struggle over college policy, which in turn seems to have been related to his conflict with the Dean of Christ Church: the father of Alice of Alice's Adventures in Wonderland. Brsck, op. cit. supra note 4 , at 192 et seq.

${ }^{2}$ Cf. Riker, supra note 5, which summarizes the Arrowian literature; BLAck, op. cit. supra note 4 ch. 7; Anthony Downs, AN Economic Theory of Democracy 60-68 (1957); and Tullock, Theoretical Forertnnets, in James M. Buchanan \& Gondon Tullock, The Calculus of Consent app. 2 (1962).

${ }^{10}$ Paul T. David et az., The Presidential Election and Transition 1960-6i, at ig (196i).

${ }^{11}$ David, Goldman \& Bain, op. cit. supra note I, at 314-I7.
} 
pull them into an order of transitivity if they had failed to achieve it. (2) Within each party, the Gallup Poll can and sometimes does provide similar trial heat data as between the candidates involved in the nominating contests, as previously noted for the Kennedy contest. When and if there is a genuine case of nontransitivity, the various polling services could be expected to discover it and might bring it to public attention, in which case one might expect enough adjustment of preferences to eliminate it-and perhaps also a more realistic public discussion than has so far occurred on the problems of nominating choice when there is in fact no genuine intra-party majority for any candidate.

To return to the question with which this discussion was opened, it cannot be said that in the present state of knowledge it is possible to create a system of voting in a national primary that would assuredly result, for each party, in the selection of the most appropriate candidate among those entered in the primary. What does seem to be certain is that in cases involving three or more candidates, a national primary with a plurality decision and no run-off could frequently be highly unsatisfactory, and a run-off merely between the two initially highest candidates could frequently be equally unsatisfactory.

A new form of primary could perhaps be devised that would meet the tests previously developed, subject to the political hazards to be discussed in the next section. If there is some such ideal form of primary election, however, it would seem appropriate to test it initially by putting it into use in the state elections of one or more states where multiple candidacies in primaries are a frequent occurrencestates that could undoubtedly use a better system of voting in primary elections than would seem so far to have been tested in practice. A successful demonstration at the state level would at least give the proponents of a national primary a better basis in principle for their position than they can currently be said to possess. ${ }^{12}$

\footnotetext{
12 The problem would especially merit further examination in connection with the electoral problems of states with a diffuse factionalism and a frequent multiplicity of candidates in primaries for major offices. The reason is not only the effect of the voting system in developing a genuine majority choice, but also in deciding whether candidates are to be drawn from the center or the extremes of the party situations concerned. As Black points out, each of the criteria he favors is "an attempt to pick out the candidate who stands highest on the average on the schedules of the electors and each tends to act against candidates who have a low ranking in the estimate of a substantial fraction of the voters; they tend to eliminate candidates who are viewed as extremists of one kind or another. If either of these criteria were used, parties of the extremities would tend to wither and disappear, while parties of the centre would prosper." BzAck, op. cit. supra note 4 , at 75 .

As applied internally within a party, this would mean that factions of the extremities would tend to wither, while the party elements of the center would prosper-a result generally considered desirable by most American political analysts, and one that might be helpful to the greater development of twoparty institutions in states where they are presently weak.

In national party conventions since 1832 , the presidential politicians have generally moved toward the center in their search for nominees who could effectively lead their party to victory in the two-party competition. This is one reason that the two-party system has survived nationally so long with a reasonable degree of competitive effectiveness. The failure of state primary election systems to accomplish a similar result probably has something to do with the corresponding failures of the two-party system in state politics.
} 


\section{Pros and Cons of a National Primary}

The theoretical considerations discussed in the previous section involve a line of reasoning that seems plausible enough, but which is still largely new and untested so far as the discussion of nominating systems is concerned. As Riker points out, the whole body of theory worked over by Black is mostly unknown to American political scientists; and while Arrow's work has been widely discussed among professional economists, it also is largely unknown to American political scientists or to American public men other than those trained in economics. ${ }^{13}$

Other aspects of the problem of a national primary, however, have been much discussed over a fifty-year period. Congressional hearings, usually focused on electoral college reform but with some attention to the nominating problem, have been held every few years. ${ }^{14}$ The academic and other literature is voluminous.

The arguments in favor of a national primary usually begin with the assumption that presidential nominations are not presently subject to popular control in either political party, and conclude that the process should be democraticized by turning over the choice to an election in which the popular vote will be directly controlling. Existing primary systems for lesser offices in the states are accepted uncritically as a good thing by the proponents of a nationary primary. The practical difficulties involved in the expansion of these systems by more than ten-fold for use by the national electorate are very largely disregarded.

Any national primary held throughout all fifty states on the same day would nonetheless be a most formidable affair. Under Senate Joint Resolution $\mathrm{x}$, the constitutional amendment currently proposed by Senator Margaret Chase Smith and four other senators, for example, no candidate would be on the ballot unless he had filed a senators, for example, no candidate would be on the ballot unless he had filed a petition signed by voters equivalent in number to one per cent of those voting in the last preceding presidential election. As Mrs. Smith has said, this would require 688,327 signers for each candidate filing in 1964. She contemplated a primary election on the first Tuesday after the first Monday in August of the presidential year, with all petitions filed at least sixty days in advance; but no petition could be circulated before January first of that year. ${ }^{15}$

The procedural requirements inherent in almost any conceivable form of national primary would have a restrictive effect on the list of candidates to be voted on in each party. Candidates seriously intending to run would be required to have their campaign organization in good working order throughout the country considerably in advance of any filing date. Candidates who were unwilling or even merely

18 Riker, supra note 5.

${ }^{14}$ For example, Hearings Before the Subcommittee on Constitutional Amendments of the Senate Committee on the Judiciary on Nomination and Election of President and Vice President, 84th Cong., Ist Sess. (1955) [hereinafter cited as 1955 Hearings]; Hearings Before the Subcommittee on Constitutional Amendments of the Senate Committee on the Judiciary on Nomination and Election of President and Vice President and Qualifications for Voting, 87th Cong., Ist Sess. Pts. 1-4 (1961) [hercinafter cited as r961 Hearings].

${ }^{15}$ See 196I Hearings 3-29, for the text of S. J. Res. I and the other proposals in amendment form; for Mrs. Smith's testimony, see id. at 69-74. 
reluctant or uncertain would have to be persuaded to be active in time, or would not be on the ballot. Under the conditions prevailing in 1952 for example, it would seem highly unlikely that General Eisenhower would have been on the Republican ballot, or Governor Stevenson on the Democratic, if a national primary had been required; the respective party candidates most likely would have been Senators Taft and Kefauver. ${ }^{16}$

Problems of campaign expense are among the most frequently mentioned reasons for opposition to a national primary. A major fund-raising operation would be the first and most essential step in mounting a campaign in an open contest in a national primary; a national campaign fund of something like a million dollars would seem a minimum requirement, even for candidates who could anticipate the support of party organizations in major states and metropolitan areas. Fund-raising on this scale would naturally require complete certainty on the availability of the candidate well in advance of the time for the circulation of filing petitions.

Senator Estes Kefauver and others favoring a national primary have repeatedly argued that the campaign funds requirement for a national primary would be no greater than it is already for the active candidates. This may be true, but it would be more essential to have large funds in hand much earlier in the process. In terms again of the events of 1952, for example, Senator Kefauver was in an excellent position to raise funds for a national campaign during March and April, after he had achieved his spectacular success in the New Hampshire primary. But in the nature of things, most of the fund-raising for any candidate in an open contest in a national primary would have to occur before there had been any dramatic test of voter enthusiasm.

Proponents of a national primary usually seem to assume that in such a primary, the party organizations would either adopt a role of neutrality, or else the primary could be used successfully by an insurgent as a forum in which to defeat the organizations. The more likely outcome would seem to be a situation in which a willing candidate could rarely develop enough backing to enter a national primary unless he had the support of the party organization of his home state, together with state or local party organization support in at least a few other states. The national primary would then become the battleground on which to fight out the cleavages among the major factions of each national party. There is little reason to think that it would provide substantial opportunities for insurgent candidates even in situations where there is genuine need for a legitimate and well-supported insurgency. ${ }^{17}$

If these speculations are correct, a national primary would in practice be an essentially anti-democratic device. It would sometimes prevent entirely the consideration of the candidate most attractive to the voters. It would freeze the field of choice

\footnotetext{
${ }^{10}$ Cf. I Paul T. David, Malcolm Moos \& Ralph M. Goldman, Presidential Nominating Polttics in 1952, at 2r9-2I (r954).

${ }^{17}$ A fuller statement of the pros and cons on a national primary can be found in I DAvip, Moos \& Goldman, op. cit. supra note 16 , ch. 6 . See also testimony of the author in $1955^{\text {Hearings } 207-17 \text {, in }}$ which he opposed all of the proposals then pending for the establishment of a national primary.
} 
many months in advance of the decision. It would provide no adequate opportunity for a progressive testing of the candidates through a series of events by which the public, and the voters and political leaders of each party, could become better acquainted with their respective merits and demerits. There would be no last minute opportunity to reconsider and look elsewhere, even if it should become overwhelmingly evident in one party or the other that all of its leading candidates were so unsatisfactory that they would undoubtedly lose the election.

For all of these reasons, it would seem that the best way to seek reform in the presidential nominating process would be through efforts generally to improve existing procedures, rather than by the substitution of a radically different procedure that could only be put in force by amending the federal constitution.

\section{Reforming the Presidential Primaries in the States}

Would-be reformers, frustrated or dissuaded in seeking a national primary, usually move next to the possibilities for reforming the existing presidential primaries in the states. A favorite plan, latent in much of the discussion and often specifically proposed, is to hold all of the state primaries on the same day, to require all candidates to enter all of the primaries, and to pledge the delegates in each state on some ironbound basis to the candidate winning in that state. In my view, all three of these proposals are misguided at best, and each of them could be dangerous in its effect on the evolution of nominating choice.

The greatest virtue of the existing system, chaotic and confused as it may be, is that it provides time to think, together with something to think about. The potential candidates are confronted with a complex series of strategic decisions and are then required to put themselves on exhibition in a variety of settings and under circumstances largely beyond their control. Not only the voters, but also the convention delegates, the party leaders, and the opposing candidates themselves, are given an opportunity to ascertain which candidates are reckless, cautious, bold, or timid; willingly candid or skillfully devious; democratic or authoritarian in their basic attitudes -all matters on which it would seem highly desirable to uncover information concerning any future President of the United States. The candidates are also given an opportunity, in fact a considerable compulsion, to unfold their attitudes on salient issues in a succession of forums where the interest in those issues is greatest, knowing at all times that what is said in one part of the country will not escape notice elsewhere.

These opportunities for public study of the candidates are almost entirely the result of features of the existing primaries that are among those most criticized. It is because the primaries are scattered from March to June and from New Hampshire to California that it is possible to study candidate performance over a period of time and in a variety of settings. The result has been the early demise of some candidacies, but the result has also been the recovery and eventual victory of some candidates who 
had the stamina to continue and enough perception to correct their early mistakes, as in Dewey's case in 1948 and Stevenson's in 1956.

Most of the primaries that attract attention and influence opinion are those that involve a straight-out fight between two candidates. These have obvious advantages for the voter, by comparison with the primaries in which no candidate is entered, or only one. The complaint most often made, however, is that when only two candidates are entered, the voters and the public are deprived because the other candidates are absent.

Yet candidates are generally well advised to avoid a three or four-way contest whenever they can. Under existing systems of plurality choice, a three-way division may easily result in tying up a state's convention votes behind the wrong candidate. In the r932 California Democratic case, for example, the vote divided Garner fortyone per cent, Roosevelt thirty-three, and Smith twenty-six; there was no run-off and Garner was given the California vote at the convention under the provisions of the California law. Yet who could prove that Garner would have defeated either Roosevelt or Smith in the California primary in a two-way contest?

In an equally famous case, the Wisconsin Republican primary of 1948 , the vote divided Stassen forty per cent, MacArthur thirty-six, and Dewey twenty-four-a division very much like the hypothetical example used earlier in this article. Dewey was the man in the middle. He probably could have defeated Stassen and MacArthur rather easily in a test against each alone, yet if there had been a run-off, it would have been between Stassen and MacArthur. It was Stassen's plurality victory in Wisconsin that gave him national stature as a candidate and made him hard to beat in Oregon. ${ }^{18}$

Pending some reform in how votes are counted in primaries, the present tendency of the candidates to stay out of the presidential primaries except where they are unopposed or where a two-candidate test is possible would seem to be one of the more important virtues of the present system. In rg6o, for example, Kennedy stayed out of the California and Florida primaries in part because each could have become a three-way contest if he had entered. ${ }^{19}$ A merely plurality victory for an unpredictable choice in either of these large states would have been no contribution to rational decision at the convention.

Delegate pledges were the third subject introduced at the beginning of this discussion. On this, it happens that there have been three separate investigations covering most of the experience of the last fifty years, in which the record of how the delegates voted at the conventions has been compared with the circumstances of their election. ${ }^{20}$ In each of the three studies, the investigators concluded that where

\footnotetext{
${ }^{18}$ For this and similar cases, see David, Goldman \& BaIN, op. cit. supra note I, at 236, 538-4I.

${ }^{10}$ David ET Al., op. cit. supra note ro, at 8-9.

${ }^{30}$ David, Goldman \& Bain, op. cit. supra note I, chs. Io and 15 and Appendices C and D; Hansen, Performance and Potential of Presidential Primary Laws, in 1961 Hearings 884 (reprinted from 39 NeB. L. Rev. 473 (I960)); James W. Davis, The Presidential Primary I928-I960 (unpublished thesis in University of Minnesota Library, I96r).
} 
the circumstances had permitted a genuinely valid popular mandate, the instances in which the delegates departed from their mandate at the convention were rare. This result occurred without much regard to whether or not there was a formal or statutory pledge; it depended primarily on whether the system of delegate election had developed some genuine expression of the popular will, and on the extent to which the candidates running for delegate had entered into some effective relationship with the candidates running for President. Formal pledges, where they existed, were usually honored, but frequently were honored too much: delegates committed by law often stayed with candidates for the nominations who had little or no popular support but who had nonetheless won primaries because opposing candidates had not entered.

Pledging requirements have frequently been put into bill form, and even actual law, without much regard to how they would work if generally in force. Under the Wisconsin formula, for example, delegates are required to vote for their candidate until release, or until his convention vote drops below ten per cent. What would happen if all delegates were elected on this basis and the convention vote was found to be divided between three candidates, each of whom was polling between twentyfive and forty per cent of the convention vote? In recent hearings, Senator Estes Kefauver was still suggesting a plan under which delegates would remain committed for ten ballots to any candidate polling more than ten per cent of the convention vote; and he proposed that if a choice could not be made on this basis within ten ballots, all candidates except the top-ranking three should be eliminated and the delegates should then choose freely among those three. ${ }^{21}$

Requirements of this kind seem almost certain to cause trouble unless there is an appropriate relationship between the convention delegates and the candidates; yet if the election system has produced such a relationship, formal pledges seem both unnecessary and undesirable. The real difficulties of the conventions arise when two leading candidates can deadlock each other, or when three or more candidates are so near each other in strength that no first-choice majority is possible for anybody. In either of these classic situations of convention difficulty, the delegates can find a solution only by shifting votes. This process is merely impeded by rigid pledges that restrict delegate judgment, just as it is also impeded when groups of delegates (and groups of voters) become so emotionally involved with their firstchoice candidates that, for them, a rational weighing of alternatives is impossible.

If the analysis presented so far is correct, the existing structure of state primaries and other systems for electing delegates is a much sounder instrumentality for developing a nominating choice than has been generally believed. If the "Arrow problem" does exist in a choice among potential party candidates in real life-and so far, no case has been proved on the basis of any form of empirical evidence-then the effect of the repeated tests and the long-drawn out campaigning is to straighten out the preferences and to eliminate the non-transitivities. More often, the problem

\footnotetext{
${ }^{21}$ 196x Hearings 273-74.
} 
seems to be one quite simply in which no candidate is firmly the majority preference of the party voters on a first-choice basis, with even greater confusion prevailing in the second- and third-choice rankings, although many voters may be quite clear in identifying their last-choice candidate-the one who would drive them into voting for the candidate of the other party. In cases of this kind, lengthy testing is indeed necessary if a firm structure of preferences is to be developed for the candidate who could be most effective as the party leader in the general election contest.

Admitting so much on behalf of the present system, it is still obvious that the various state election laws are replete with useless idiosyncrasies that confuse the voters and distract the candidates. In previous research, many specific proposals were made, but the two state systems most recommended for the favorable attention of the reader were those of New York and Florida as they existed in 1956 and $1960 .{ }^{22}$

The New York system provides for the separate election of the district delegates by primaries in the several congressional districts, while the delegates at large are elected by the state party committees. There is no presidential preference vote, and the would-be delegates are not allowed to show their preference on the ballot, although free to indicate their preferences while campaigning. The virtues of the system are those of any public election, with a short-ballot choice for the voter and a clear relationship between the voters and their representatives at the convention. The system gives little opportunity for a direct expression of popular choice among the presidential candidates, but New York voters have seldom had much reason for discontent over the behavior of their delegations at the conventions.

The Florida statute of I955 sought to bring together the best features of the previous Florida, South Dakota, New Hampshire, and Wisconsin systems. ${ }^{23}$ Under the Florida law, would-be delegates may run only as members of organized slates. Each slate must contain a full quota of candidates for delegate-at-large, together with a full quota of district delegate candidates for at least half the congressional districts in the state. Delegates-at-large are elected on the basis of the state-wide vote, district delegates on the basis of the vote in each district; plurality votes control in each case, with no run-off.

Each slate is authorized to run under the name of its preferred presidential candidate if it has a preference; his name appears on the ballot above the slate, and the voter indicates his choice among slates by making a single mark. The delegates are not required to give any pledge and may indicate their preference on the ballot for any candidate without securing his consent. If more than one slate preferring the same candidate is filed, however, the candidate is authorized to choose the one to go on the ballot; otherwise the one filed first is the one to appear. (Latent in this provision is the candidate's privilege of organizing and filing his own slate if he

${ }^{22}$ David, Goldman \& Bain, op. cit. supra note I, at ch. 10, 491-94.

${ }^{23} \mathrm{~A}$ memorandum prepared by the writer was the basis for discussion and was largely followed; the memorandum, later issued as a Brookings Institution reprint, may be found in 1961 Hearings 867. See also Dauer et al., Tosuard a Model State Presidential Primary Law, 50 Am. Por. Scr. Rev. ${ }^{8} 8$ (1956). 
disapproves of any slate that is making use of his name.) "No-preference" slates are also authorized to file, without restriction on the number of such slates, and can be voted on as units. There is no provision for any preference vote separate from the election of delegates; the mandate is expressed entirely through the election of delegates who have either stated their preference or advised the voter that they have no preference as of the time of filing.

In 1956 , this law producd the contest between delegations favoring Kefauver and Stevenson, in which Stevenson was the winner; on the Republican side of the ballot, a Knowland delegation was defeated by an Eisenhower delegation, filed without need for any formal action on his part. In I960, there was no contest in either party; Democrats elected a delegation favoring Senator George Smathers, and Republicans elected a delegation favoring Vice President Richard Nixon. An attempt to amend the law to disengage the delegates from the candidates and to restore a purely advisory preference poll was vetoed by Governor LeRoy Collins in 1959, and for the time being at least, the 1955 statute seems likely to remain in effect. It has the possibility of making Florida the scene of one of the more interesting contests in the Republican Party in Ig64.

The Florida law has many virtues. Despite the circumstances prevailing in the state in 1960 , the Florida law can generally be expected to put a choice before the voters whenever campaigns are under way with a high potential of voter interest. It may occasionally produce a three-way contest with an unsatisfactory outcome under plurality voting, but both the historical experience with this type of law and the recent tendencies of candidates would indicate that contests are more likely to be confined, under such a system, to the two candidates with the greatest potential in the state. The Florida system can put a candidate into a race from which he might prefer to be omitted, but in that case, the candidate can always leave the burden to the would-be delegates who are using his name-as Eisenhower undoubtedly would have done if the system had been available on the Republican side in Florida in 1952. In any event, this aspect of the Florida system is essential if the possibility of a draft is to be mantained; and conversely, it has been repeatedly demonstrated that the systems requiring candidate consent usually degenerate into systems that typically offer only a favorite son and no choice for the voter. ${ }^{24}$

At an earlier time, it was my concern that the Florida system, if generally adopted, might lead all too frequently to party-splitting fights in states where the two-party system was otherwise in a relatively healthy condition. This is an aspect of the problem that will undoubtedly continue to concern the party organizations. But

\footnotetext{
${ }^{24}$ Because the voter makes only one mark in voting for an entire slate, the Florida system would be relatively easy to adapt to a revised system of alternative voting along the lines diseussed carlicr in this article. If such a system is not feasible, however, it should be noted that plurality choice is far less dangerous in a decentralized system of state primaries than it would be in a single national primary, and especially where the outcome can vary from congressional district to district, as under the Florida system. If the Florida system were in general use, it could be expected that candidates and their supporters would be selective about the states they cntered, and that unjustified plurality gains in some states would be offset by losses elsewhere.
} 
the Florida experience in 1956 and 1960 and that of other states over a longer period, does not support the conclusion that party-splitting contests will be excessively frequent, and on occasion they may be desirable. A general adoption of the Florida system would not necessarily lead to seriously adverse consequences for any aspect of the general political system. It comes so much closer than any other proposal to meeting the general desire for popular control, while also preserving desirable elements in the existing process for making presidential nominations, that it would seem to merit congressional consideration as a plan to be recommended to the states. This suggestion was made at the most recent congressional hearings. ${ }^{25}$

\section{Reforming the National Conventions}

Unnoticed in the hoopla attending the national party conventions, there have been important changes since World War II in the manner in which these assemblies perform their functions. ${ }^{26}$ More of the business has been transacted in advance; and much more than formerly, the conventions have become forums for the final consummation of decisions already in view rather than the places at which the decisions are actually developed.

Nominating campaigns in advance of the conventions have involved more overt activity by the candidates, the voters have been more consulted, the primaries have evolved into a series of decisive tests, the public opinion polls have provided a series of running indicators on candidate standing, and the mass media have reverberated the results of both primaries and polls throughout the country. Delegate intentions are tabulated and re-tabulated in advance of the conventions, and delegates find it increasingly difficult to reserve their own decisions until the conventions meet. The result is to bring the nominating decision to a high state of preparation before the actual voting, although aspects critical to the outcome may still turn on vote-shifting that can only occur after the actual convention balloting begins.

Other aspects of convention activity are also increasingly prepared in advance. The custom of having the platform committees meet for a week in advance of each convention is of recent origin, but now seems well established. Other committees also usually meet soon enough to permit reporting without delay when the conventions are ready for them-a change that has made it possible to keep the business of each convention actively in motion from the time when it opens until it adjourns. This possibility could be more fully exploited than it has been, and in time it probably will be.

Despite these changes in their inner life, the conventions retain their characteristic appearance and have undoubtedly retained their characteristic deficiencies. The appearance is a matter of behavioral traits that are typically American and that will not easily be suppressed, although some basic changes in convention structure might also help on behavior. The characteristic deficiencies that are important are primarily

\footnotetext{
${ }^{25}$ I96I Hearings Pt. 2, at 419-23.

${ }^{20}$ Cf. Tillett, The National Conventions, in David ET AL., op. cit. supra note ro, ch. 2.
} 
(I) those of size, which complicates all procedures through which a vote may be developed and then accurately taken and recorded; (2) of distribution of voting power among the states, a fundamental problem for any voting assembly; and (3) of how the delegates carrying the votes are selected, the problem discussed in the previous section.

For most of a century, the conventions followed the rule that each state's delegation should be double the number of its representatives in the Senate and House of Representatives. Currently applied, this would produce conventions of about Iroo members each-large numbers but not so large as to prevent floor debate when it is adequately organized or to produce excessive difficulties in taking a roll call vote by delegations. The I960 Republican Convention at Chicago was still near this size, with I,33I votes and I,33I delegates. The I960 Democratic Convention at Los Angeles, however, was held under rules that resulted in 1,52I votes distributed among about 3,000 delegates, most of whom held one-half of a vote. Delegation headquarters were scattered from Pasadena to Hollywood, the supply of hotels with meeting rooms large enough to hold a delegation was insufficient, and the deliberative processes that go on among and within delegations were more seriously hampered than ever before.

This experience was at least a part of the inspiration for a bill introduced in the present Congress by the Senate majority leader, Mike Mansfield, who proposes that each major party be given a million dollars from federal funds to assist in meeting its radio and television expenditures in each presidential campaign if it will hold its convention in September, thus shortening the campaign, and if it will restrict the size of its convention to not more than $54 \mathrm{r}$ members, with no fractional voting. Each state would be given as many delegates as it has representatives in the two Houses of Congress, with up to six votes for other areas such as Puerto Rico and the District of Columbia. ${ }^{27}$

A restriction on size as severe as that proposed by Senator Mansfield does not seem necessary, but it would be highly desirable to return each convention to a membership of not much more than one thousand. This would be sufficient to permit two members from each congressional district as a normal rule; and it would provide a convention large enough to permit the inclusion of the public and party officials of high rank who need to be present in the conventions as voting members, while still leaving room for other delegates drawn more largely from the party rank-and-file. At the 1956 conventions, for example, 395 Democratic delegates and 233 Republican were public and party officials, present or former, of high rank: governors, senators, representatives in Congress, national committee members, and others of comparable rank. An increasing tendency to include such figures as delegates has brought on a considerable change in the composition of the conventions

${ }^{27}$ S. $227,87_{\text {th }}$ Cong., Ist Sess. (196r). 
in recent years, and has undoubtedly made them more important than formerly as party governing bodies and as joint rallies for the presidential and congressional campaigns. $^{28}$

The apportionment of convention votes among the states is a subject in which there has rarely been much public interest, but the problem is one that reached crisis proportions in the Republican Party during the period from Ig08 to I9I6. Academicians have advocated that the convention votes be allocated among the states in proportion to the party following in each state, as measured by the turnout in the most recent presidential election. Republican rules were modified in that direction after the party split of I9I2, and in recent years both parties have given "bonus votes" that tend to increase the voting strength of the states that remain faithful to the party. In both parties, the present rules leave much to be desired, but the problem of bringing about any improvement is difficult. The technical aspects of the problem have been given extensive attention in recent research. ${ }^{29}$ The Democratic rules were left in sufficient disarray at the most recent convention to create new political difficulties and to suggest further attention before the convention meets in $\mathrm{x} 964$. The national committee passed a resolution authorizing a further study when it adopted the r 960 apportionment. ${ }^{30}$

Most representative bodies find it difficult to deal rationally with their own apportionment problems; the conventions are no exceptions. This would seem to suggest the area as one in which Congress might well take jurisdiction for the conventions; the Mansfield bill noted above may be a step in that direction. At hearings on the bill, the discussion turned almost immediately to the difficulties in deciding what constitutes fair representation for the several states in a party convention. ${ }^{31}$

The selection of delegates, as suggested above, is another subject to which Congress might well give attention. A few members have long sought to do so, but mainly through proposals for constitutional amendments. In 1952, however, Senator Paul H. Douglas and Representative Charles E. Bennett initiated a new type of statutory proposal under which the federal government would contribute to the expense of holding presidential primaries in those states where primaries are held in accordance with specifications laid down in the federal statute. This was a breakthrough to a new formula for legislative action that may still succeed; as attempted initially, however, the details of the proposal were subject to most of the same criticisms that can be brought to bear on the proposals for a national primary. ${ }^{32}$

With minor changes, the Douglas-Bennett bill was re-introduced in successive

${ }^{28}$ David, Goldman \& Bain, op. cit. supra note $x$, at 213-17, 342-49.

${ }^{20}$ Id. ch. 8, and 193-99.

${ }^{80} \mathrm{Id}$. at I9r.

${ }^{31}$ Hearings Before the Subcommittee on Privileges and Elections of the Senate Committee on Rules and Administration, 87th Cong., Ist Sess. 35-50 (I96r).

${ }^{32}$ I David, Moos \& Goldisan, op. cit. supra note I6, at 217-24. 
Congresses; in the present Congress, a considerably rewritten version was introduced by Senator Mike Mansfield as part of his package of three bills to reform the nominating and election processes. ${ }^{33}$ The Mansfield bill, however, retained features for putting the candidates on the ballot that are procedurally difficult, that could lead frequently to contests in the states among three or more candidates, and that would make it almost impossible to draft a reluctant or uncertain candidate. The basic approach of the bill also makes necessary a federal administrative agency to accept filing petitions and supervise the system, a feature that is not likely to recommend the proposal to the states.

Federal legislation recommending the Florida type of primary to the states would seem preferable, if the analysis presented here is correct. Under such legislation, there would be no need for any elaborate federal administrative apparatus, because there would be no occasion for any central filing of nominating petitions on behalf of candidates for the presidential nominations. Legislation along such lines would seem more attractive to the states, and such a proposal would thus seem more likely to prosper in Congress whenever its basic concepts come to be more generally understood.

Recently some students of the party system have argued that popular control over the nominating process is already so ascendant that no party convention would dare to reject the popular choice. The view has been put most forcefully by Professor William G. Carleton: ${ }^{34}$

National nominating conventions no longer select dark horses or even favorite sons. They now endorse a national favorite, usually the outstanding favorite, as measured by victories in the primaries and ratings in public opinion polls. Political leaders and delegates in national conventions are being reduced to rubber stamps.

As the quoted statement suggests, however, no matter how complete the appeal to popular opinion may become, there is always the possibility that there may be more than one popular favorite in an open nominating situation. It cannot be said with assurance that the pre-convention proceedings will eliminate all of the candidates but one; if it could, there would be even greater need for reforming the procedures by which this result is to be accomplished. And when the conventions do find themselves faced with a choice among two, three, or even four candidates, each of whom has managed to survive the pre-convention proceedings with some degree of popular acclaim, the convention's problem would seem not less difficult but more. It can reject no one without infuriating a substantial body of voters.

Under such circumstances, it would seem foolish indeed to argue that there is no need for reform because the voice of the people will inevitably settle the issue despite

${ }^{33}$ S. 228 , 87th Cong., Ist Sess. (196r). See his statement in ro7 Cong. REc. 347, 349-52 (rg6r), when he introduced the bills.

'st Carleton, The Cult of Personality Comes to the White House, Harper's Magazine, Dec. 196r, pp. 63, 64; Carleton, The Revolution in the Presidential Nominating Convention, 72 Por. Scr. Q. 224 (1957). 
the disjointedness of the machinery. A substantial body of new information has been accumulated in the major researches of the past ten years, and there has been a considerable increase in the number of scholars working independently on research with respect to various facets of the nominating process. If Congress and the Administration decide seriously to give active consideration to federal legislation on presidential nominations, qualified professional assistance will be much more available to assist in solving the problems than was ever before the case. 